\title{
ELECTRONIC PROPERTIES MODELLING UNTUK BOTOL AIR MINUM KEMASAN
}

\author{
Yohanes Calvinus ${ }^{1}$
}

${ }^{1}$ Jurusan Teknik Elektro, Universitas Tarumanagara

Email:yohanesc@ft.untar.ac.id

\begin{abstract}
ABSTRAK
Air minum kemasan telah menjadi kebutuhan untuk manusia. Banyak orang beranggapan bahwa air minum dalam kemasan menjadi sebuah jaminan kualitas kesehatan. Padahal tidak sedikit beberapa orang beranggapan juga berdasarkan ukuran Standar Nasional Indonesia dan BPOM yang tercantum pada kemasannya membuat orang meragukan kualitas dan kesehatannya. Berdasarkan informasi yang didapatkan dari media online cnn Indonesia pada hari kamis tanggal 27 Juli 2017, ada 3 syarat yang menjadikan standard air minum berkualitas. 3 syarat tersebut adalah syarat fisik, syarat mikrobiologi, dan syarat kimia. Belum ada termasuk dalam standard air minum kemasan tersebut memiliki syarat secara elektronis. Untuk membangun suatu standard air minum kemasan dengan syarat elektronis maka dibutuhkan suatu pemodelan dalam bentuk rangkaian elektronik yang menggambarkan suatu nilai pengganti yang mewakili ketiga standard air minum yang berkualitas. Melakukan pemodelan dalam bentuk rangkaian listrik terdiri dari ketiga komponen elektronika yaitu resistansi, induktansi dan kapasitansi. Bentuk rangkaian model yang dikemukakan yaitu rangkaian RC yang dihubungkan seri dan L yang terhubung seri meskipun keluaran dari rangkaian ada pada sifat induktansi nya. Diharapkan dari pemodelan ini dapat menjadi suatu nilai ukuran atau standard nilai baru dalam menentukan kadar air minum yang lebih berkualitas. Dari nilai standard ukur elektronis ini tentunya akan sangat membantu menciptakan alat ukur elektronik yang lebih baik agar alat ukur ini dapat dipergunakan menjadi standard air minum berkualitas yang bisa dimiliki setiap manusia yang ingin meminum air minum kemasan.
\end{abstract}

Kata kunci: syarat elektronis; syarat air minum berkualitas; pemodelan rangkaian listrik; nilai elektronis; standard air minum elektronis

\begin{abstract}
Bottled water has become a human need. Many people think bottled drinking water is a guarantee of health quality. Meanwhile, some people think that they are also drafting Indonesian national standards and BPOM that approves packaging makes people doubt their quality and health. Based on information obtained from online media in Indonesia on Thursday 27 July 2017, there are 3 conditions that make quality drinking water standards. These 3 requirements are physical requirements, microbiological requirements, and chemical requirements. Not yet in the standard of bottled water that has electronic requirements. To make standard drinking water with electronic requirements, we need a modeling in the form of plastic in accordance with an assessment that represents quality drinking water. Modeling in the form of an electrical circuit consists of three electronic components, namely resistance, inductance and capacitance. The form of the series of models proposed is that the RC circuit releases the series and the L connected series removed from the circuit is in its inductance. It is expected that this modeling can become a new standard or standard value in determining higher quality drinking water content. From the value of this electronic measuring standard will greatly help create a better electronic measuring device so that this measuring instrument can be used to be a standard of drinking water quality that can be provided by every human who wants to drink bottled water.
\end{abstract}

Keywords: electronic requirements; quality drinking water requirements; electrical circuit modeling electronic values; electronic drinking water standards 


\section{PENDAHULUAN}

Sebagai bagian dari masyarakan Indonesia yang mengkonsumsi air minum dalam kemasan (AMDK) tentunya khawatir akan kualitas air minum dalam kemasan yang bisa saja menjadi konsumsi harian bahkan setiap jam. Kualitas Air minum dalam kemasan hingga saat ini memang menjadi tolak ukur untuk kualitas terbaik air minum hingga saat ini. Berdasarkan data yang diambil dari beberapa media kabar elektronik, diketahui bahwa ternyata 39\% konsumsi amdk ini ada di Jakarta. Sungguh ironis buat warga jakarta apabila air minum yang dikonsumsi ini ternyata memiliki standard tidak layak namun tetap dikonsumsi oleh warga Jakarta.

Sebagai persaingan bisnis di dalam memproduksi amdk, pemerintah serta merta mengikuti dan memonitoring standard air minum di Indonesia terutama ada beberapa instansi yaitu BPOM, ASPADIN, dan lain-lain. Belum lama ini dalam tahun 2018 dihebohkan bahwa ada indikasi amdk beberapa merk mengandung mikroplastik yang berbahaya bagi tubuh. Menurut ketua Aspadin, Bp. Rachmat Hidayat, selama ini belum ada ketentuan uji baku dan ketentuan lainnya yang menentukan standard baru untuk kualitas air minum dalam kemasan dalam hal ini membahas keberadaan mikroplastik dalam amdk.

Untuk mengetahui kualitas air dapat kita bawa ke laboratorium dan hasil yang didapatkan dari salah satu pengukuran laboratorium dapat kita lihat pada Gambar 1. Hasil Pengukuran Air dari Laboratorium.
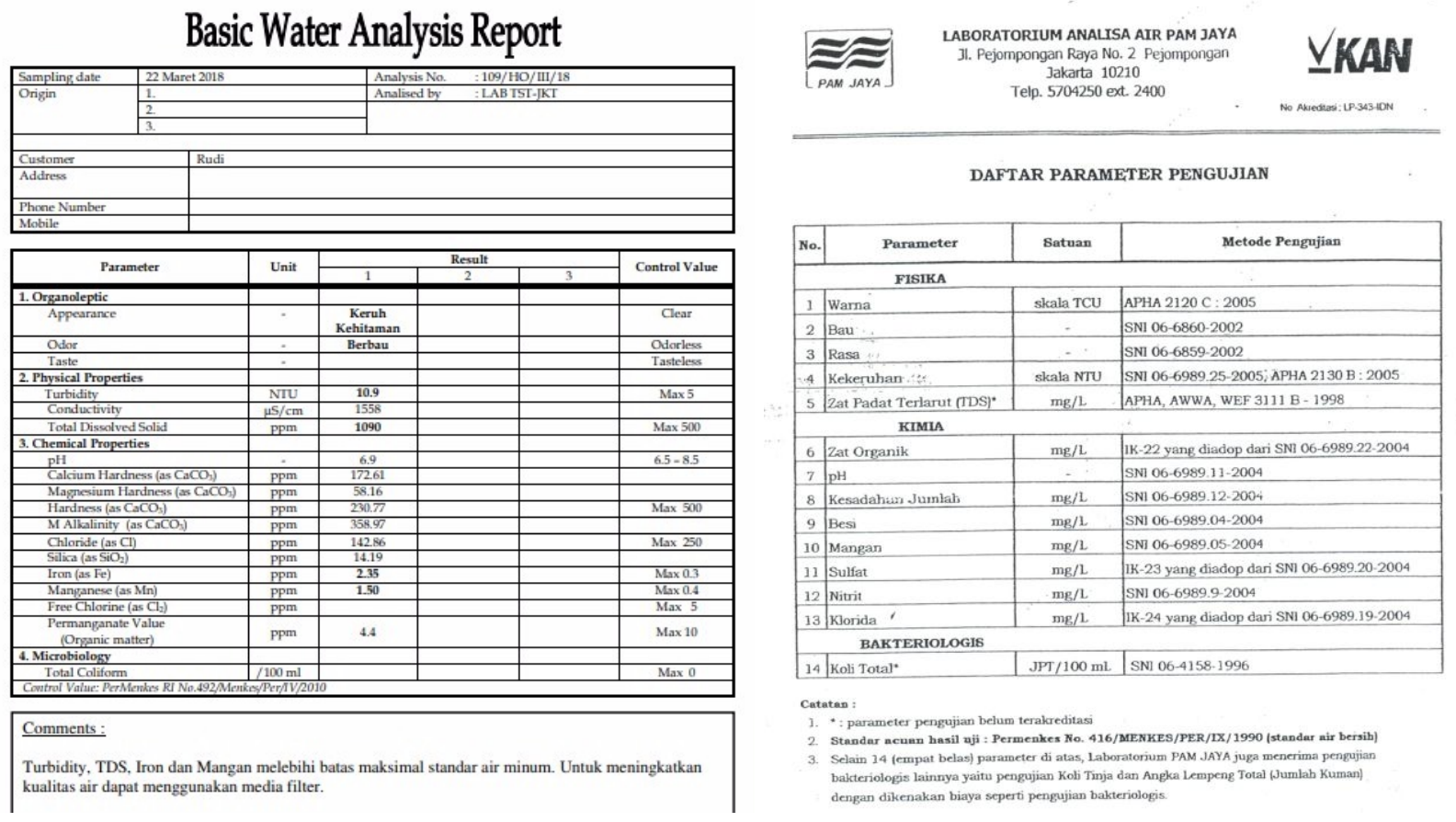

Gambar 1. Hasil Pengukuran Air dari Laboratorium

Mahal nya biaya untuk melakukan uji air di laboratorium dapat dilihat pada lampiran 1 dan lampiran 2. Waktu untuk uji mutu kualitas air tentu juga membutuhkan waktu lebih lama dari 3 hari pengujian. Pengujian yang dilakukan oleh badan pemerintahan yang bekerjasama dengan beberapa BUMD pemerintah seperti pada laboratorium PAM JAYA juga membutuhkan waktu antara 1 hingga 2 minggu dengan biaya minimal Rp 200.000,- hingga Rp 600.000,- . Terlihat dari gambar 1., pengukuran di laboratorium terdiri dari fisika, kimia, dan bakteriologi. 
Pengukuran elektronis ini menjadi penting agar suatu saat ada suatu standard pengukuran air minum kemasan yang memiliki standard ukur elektronis. Dalam hal ini diteliti bahwa kadar kandungan secara fisik, chemical dan microbiology dapat dihubungkan ke dalam suatu nilai elektronis. Electronic Properties yang terkandung dalam air minum harus ditentukan agar dikemudian hari dapat dianalisa bahwa air minum sehat memiliki kadar Electronic Properties yang dapat menjadi acuan atau standard nasional Indonesia. Adapun komponen elektronika yang diasumsikan dapat menggantikan sifat dari karakteristik dari air minum dalam kemasan yaitu resistansi , kapasitansi dan induktansi. Sifat dari karakteristik ini memiliki hubungan erat dengan karakteristik kimiawi. Dimana unsur mineral dalam kandungan air dinilai memiliki sifat konduktor sebagai penghantar listrik yang baik. Pada air destilasi / air suling / disebut juga air minum reverse osmosis tidak memiliki kandungan mineral, maka air reverse osmosis ini malah menjadi isolator yang baik. Berdasarkan TDS meter - air ini malah bernilai baik karena tingkat kandungan dissolved solid nya sedikit.

Mineral dalam air dapat terionisasi dengan listrik - terkadang air yang mengandung mineral banyak juga belum tentu memiliki tingkat kualitas air minum yang baik. Banyak anggapan di masyarakat di dunia tentu nya bahwa ada 2 kategori air minum yang baik yaitu air reverse osmosis dan air ber-mineral dengan ph diatas 8.5 . Tentunya ini menjadikan anggapan di kalangan masyarakat antara pro dan kontra akan pemahaman ini.

Diharapkan dengan pemodelan rangkaian listrik yang bisa menggantikan sifat dan unsur di dalam kadar air minum ini membuka celah untuk para peneliti melakukan penelitian di bidang elektronika dan kesehatan lebih mendalam. Air minum dalam kemasan di model kan dalam bentuk suatu rangkaian seri/parallel antara sebuah resistansi dan kapasitansi dan dihubungkan seri/paralel dengan rangkaian induktansi yang dapat menggantikan fungsi dan analogi dari komponen atau sifat air minum dalam kemasan tersebut.

\section{MENGUKUR KUALITAS AIR}

Kualitas air minum yang baik secara fisik adalah tidak berbau, tidak berasa, dan jernih. Namun secara kimiawi kita ketahui bahwa air memiliki ph (tingkat asam) harus diatas ph 7.0 (air layak minum). Beberapa air minum dalam kemasan yang dikonsumsi dan beredar di Jakarta memiliki ph diatas 7.0 , hingga ph 8.5 untuk air minum dalam kemasan. Menurut beberapa orang dipercaya dengan ph yang lebih tinggi, maka air akan lebih baik. Beberapa cara secara elektronik sudah dilakukan namun hingga saat ini dengan pengukuran TDS meter dan water conductivity masih di pertanyakan dan belum bisa menjadi komponen standard elektronis. Tentunya dalam pengukuran ph meter sangat berpengaruh pada sifat dari resistansi air tersebut.

\section{Total Dissolve Solid Meter}

TDS meter tidak dipengaruhi oleh ph air. TDS meter membaca nilai dari kandungan mineral di dalam air per million. Kadar yang dianjurkan untuk air minum menurut tds meter yaitu semakin kecil maka akan semakin baik, dalam hal ini air reverse osmosis adalah yang terbaik. Dimana air yang tidak mengandung mineral - maka listrik tidak dapat mengalir atau merambat di air tersebut. Hal ini menyebabkan sifat dari konduktivitas nya menjadi sangat rendah hingga tidak bernilai. 


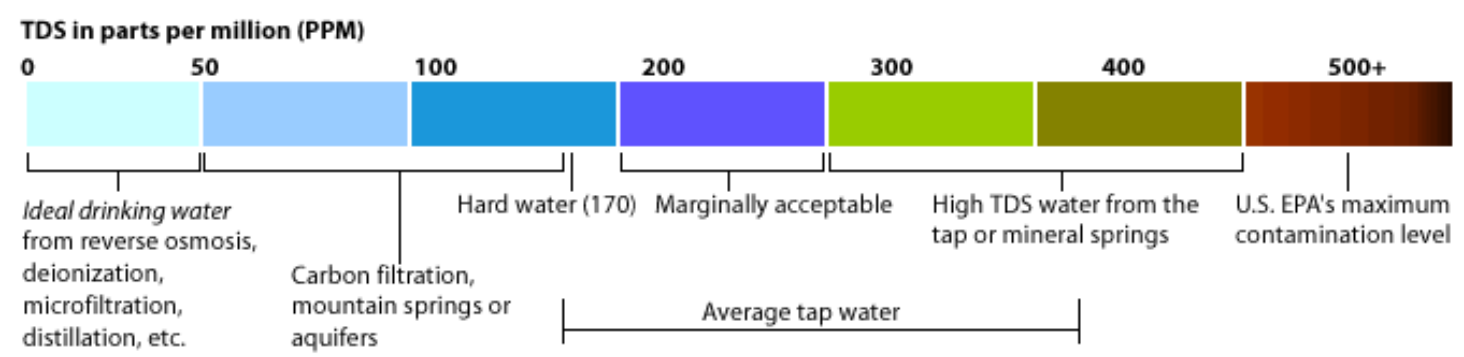

Gambar 2. Pembacaan TDS meter \& artinya.

TDS meter membaca nilai kation dan anion secara utuh dalam kesatuan akan tetapi TDS meter tidak dapat memberikan gambaran antara hubungan kation dan anion.

Rumusan TDS pada umumnya :

$\operatorname{TDS}(\mathrm{mg} / \mathrm{l})=0.5 \times E C(\mathrm{dS} / \mathrm{m}$ or $\mathrm{mmho} / \mathrm{cm})$ or $=0.5 * 1000 \times E C(\mathrm{mS} / \mathrm{cm})$

$\mathrm{EC}=$ electricity conductivity $;$ TDS $=$ Total Dissolved Solids

Hubungan antara TDS (ppm) dan EC sebagai berikut :

$1 \mu S / \mathrm{cm}=1.10^{-6} \mathrm{~S} / \mathrm{m}$

$1 \mu S / \mathrm{cm}=0.5 \mathrm{ppm}$

Dalam pernyataan menurut WHO yang dikemukan lewat publikasi pada buku "guidelines for drinking water quality" pada tahun 1996, dengan nomor WHO/SDE/WSH/03.04/16. Nilai dari TDS meter tidak ada data yang benar valid yang dapat mengaitkan nilai tersebut dengan kesehatan pada air minum. Namun lebih daripada itu, banyak asosiasi dan badan kesehatan lainnya mengupayakan hal lain yang menjadi pengaruh utama dalam validasi kualitas air minum yang baik bagi kesehatan.

Salah satu contoh nya pengaruh mikroplastik yang menurut media kabar pada awal tahun 2018 dengan adanya penemuan mikroplastik pada air minum dalam kemasan pada beberapa merk ternama di dunia.

\section{Electricity Conductivity}

Water conductivity atau disebut dengan electricity conductivity merupakan kekuatan dari sifat air tersebut untuk menghantarkan listrik, maupun gelombang suara dan gelombang panas. Dalam water conductivity memiliki satuan siemens per meter $(\mathrm{S} / \mathrm{m})$ pada satuan standard international. Rata-rata Konduktivitas air minum dalam kemasan layak minum memiliki besaran sebesar $0.005 \mathrm{~S} / \mathrm{m} \mathrm{s} / \mathrm{d} 0.5 \mathrm{~S} / \mathrm{m}$. Dalam hal ini electricity conductivity berhubungan erat dengan nilai dari TDS meter diatas. Sebagai contoh air dengan tanpa mineral - tentu nilai konduktivitas nya malah "0", artinya aliran listrik tidak dapat di hantarkan dengan baik di dalam air minum dalam kemasan. 


\section{ELECTRONICS PROPERTIES MODELING}

Dalam menggambarkan rangkaian listrik pengganti air minum dalam kemasan ke dalam bentuk rangkaian elektronik yaitu R, L, dan C. maka secara logika diperlukan hal yang dapat mewakili bagian dari R, L dan $\mathrm{C}$ tersebut. Rangkaian RLC biasa nya digantikan dengan suatu rangkaian pengganti yang disebut rangkaian impedansi (simbolnya : Z). Nilai Impedansi ini bernilai vektor dan dapat dipergunakan untuk menjadikan suatu rangkaian dengan gelombang elektromagnetik.

Membahas electricity conductivity yang memiliki satuan siemens. Satuan siemens sendiri merupakan satuan turunan dari nilai Ampere / Volt atau sama dengan 1/Resistansi $\left(\Omega^{-1}\right)$. Sehingga apabila konduktivitas nya bernilai " 0 " maka itu artinya sama dengan nilai resistansi juga bernilai "0". Satuan siemens sendiri merupakan perubahan dari nama satuan Mho (ひ).

Secara logika apabila R menjadi "0" (nol) hanya bisa apabila hubungan R dan C bersifat seri dimana kapasitansi pada air merupakan analogi dari kandungan mineral dalam air juga bernilai "0". Sebagai gambaran lihat gambar 3.

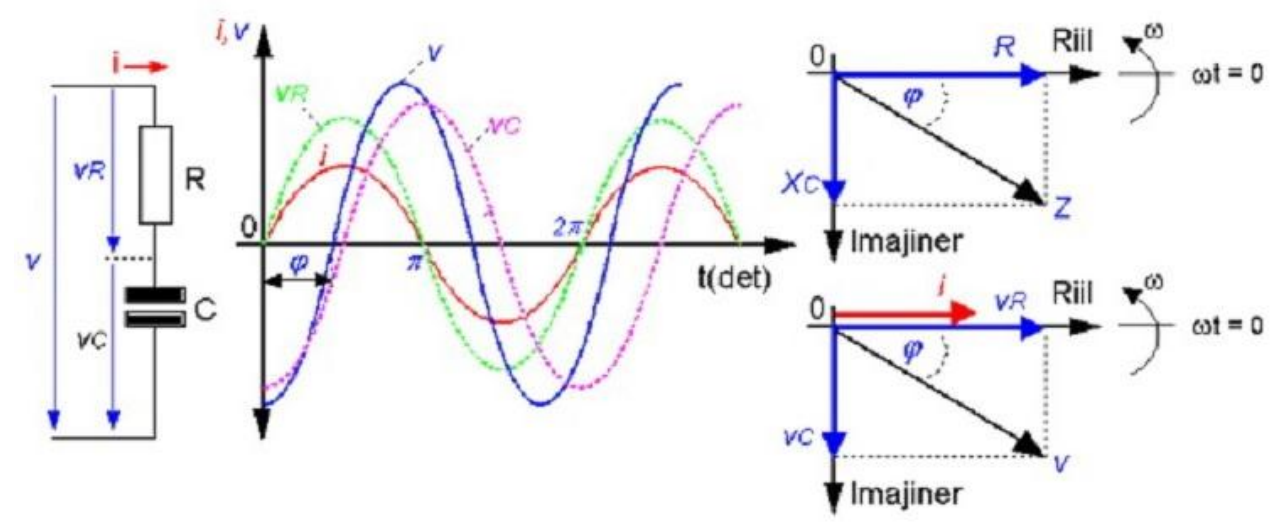

Gambar 3. Rangkaian Seri R \& C

Apabila pada komponen $\mathrm{C}$ yang dianalogikan sebagai bagian dari kandungan mineral dalam air minum dalam kemasan maka pada air destilasi (air murni) kandungan mineral bernilai " 0 " maka pada rangkaian R tentunya akan memiliki nilai " 0 " juga karena pada dasarnya rangkaian $\mathrm{RC}$ seri diatas terputus oleh karena nilai $\mathrm{Vc}$ menjadi nol dan tidak ada arus yang mengalir melalui nya sehingga nilai pada konduktivitas (1/R) akan bernilai " 0 ” juga.

Untuk komponen Induktansi digambarkan bahwa komponen ini mampu menghantarkan arus atau mengubah suatu bentuk medan magnet atau menjadi suatu arus atau komponen energi lainnya. Sifat air ini sama dengan saat kita memasukkan air ke dalam microwave dimana ketika air yang diberikan gelombang electromagnetic akan mengubah gelombang electromagnet tersebut menjadi suatu nilai arus yang akhir nya mengubah arus tersebut menjadi energi panas. Dalam hal ini induktansi berlaku sebagai susceptor yang memiliki kemampuan untuk mengabsorbsi energi gelombang electromagnet menjadi energi panas. Hubungan susceptor / induksi diasumsikan sebagai rangkaian seri sehingga rangkaian akhir nya digambarkan pada gambar 4. Susceptance bernilai imaginer dari nilai admittansi. Admittansi adalah suatu nilai terukur yang menggambarkan suatu komponen elektronika mampu menghantarkan arus yang mengalir di dalamnya. 


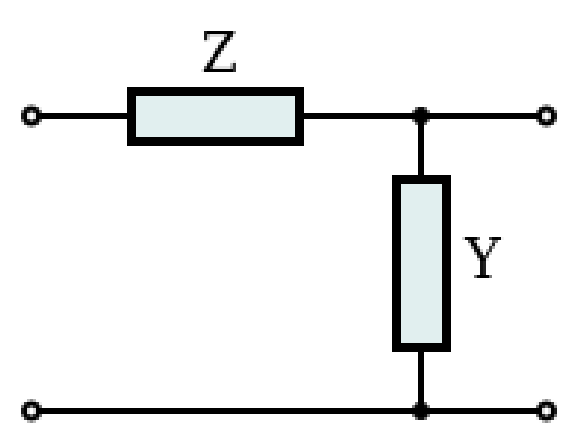

Gambar 4. Susceptor (induktor) pada huruf Y , sedangkan $\mathrm{Z}$ merupakan rangkaian RC yang dihubungkan seri (pada Gambar 3.)

Dari rangkaian pada gambar 4. Maka bisa saja rangkaian dihitung dengan metode linierisasi variabel waktu ke dalam variabel frekuensi. Contoh perhitungan digunakan pada rumus (2).

$X_{t}=A X_{t}+B U_{t}$ dan $Y_{t}=C X_{t}+D U_{t}$

Dalam domain waktu.yang nanti nya diubah menjadi domain Frekuensi (Laplace Transform)

Dari rangkaian pemodelan elektronika diatas diharapkan dapat ditemukan suatu nilai frekuensi yang menggambarkan suatu nilai yang tetap dan dapat menjadi acuan untuk banyak air minum dalam kemasan. Dibayangkan bahwa suatu saat akan ada alat ukur dengan mengirimkan gelombang ke dalam air minum kemasan - dan dapat diketahui oleh alat tersebut bahwa air minum dalam kemasan tersebut dapat dikonsumsi atau tidak nya.

\section{KESIMPULAN DAN SARAN}

Dalam hal ini pemodelan rangkaian listrik yang menjadi analogi RC dihubungkan seri dan dihubungkan dengan rangkaian Induktansi sebagai suatu sistem yang berada dalam domain frekuensi atau pun waktu. Pemodelan ini ditujukan agar penelitian selanjutnya dapat didalami untuk setiap nilai dari konduktivitas dan susceptor (admittansi) yang ada ke dalam percobaan ke dalam berbagai merek air minum dalam kemasan. Hasil nilai pengukuran nanti nya juga dalam Siemens per satuan luasan waktu. Apabila ini berhasil maka dapat dikembangkan alat ukur yang terpatenkan agar nilai frekuensi tersebut merupakan standard layak air minum dalam kemasan secara elektronis.

\section{Ucapan Terima Kasih}

Peneliti mengucapkan terima kasih kepada kedua orang yang mendukung penelitian \& memberi semangat yaitu Ibu Ir. Endah Setyaningsih, MT dan Bp. Joni Fat,ST,ME. Terima kasih juga ditujukan kepada penyelenggara seminar nasional multi disiplin 2018 memberikan kesempatan untuk dipublikasikan dalam seminar nasional yang diadakan di Universitas Tarumanagara pada tanggal 23 - 24 maret 2018. Dan tidak lupa untuk berterimakasih untuk keluarga tercinta yang memberi dukungan semangat dan waktu. Semoga penelitian ini bisa diteruskan dalam berbagai penelitian selanjutnya dan bisa bermanfaat juga untuk masyarakat Indonesia. 


\section{REFERENSI}

Thanos Antoulas. (2004). State Spaces Systems. Rice University. Houston - Texas.

W Kauzmann \& D Eisenberg.(1969). The Structure and Properties of Water. Clarendon Press. Oxford - England.

Giancarlo Franzese \& H. Eugene Stanley. (2006). Understanding the Unusual Properties of Water. Cornell University Library. Simons Foundation. New York - USA.

Eugene H. Trinh. (1978). The properties and structure of liquid water, an overview. Office of Naval Research. Yale University. Connecticut - USA.

YaoquanTu \& AattoLaaksone. (2000). "The Electronic Properties of water molecules in water clusters and liquid water".chemical physics letters, vol. 329 issues 3-4, 283-288.

J.P Caliste, A.Truyol, J. H Westbrook. (1998). Thermodynamic Modeling and Materials Data Engineering. Springer - Verlag Berlin Heidelberg.

Henry C. Lukaski, Phyllis E. Johnson, William W. Bolonchuk. (1985). Assement of Fat-free Mass Using Bioelectrical impedance measurements of the human body. The American Journal of clinical Nutrition. Oxford University Press - England.

James Baker-Jarvis.(2010). "Characterization of Tissue Equivalent Materials for High Frequency Application”. NIST Technical Note 1554. Gaithersburg, Maryland - USA

L.Marton and C.Marton. (1981). Advances in Electronics and Electron Physics. Academic Press - Harcourt Brace Jovanovich Publisher. California - USA.

V.L. Moruzzi, J.F Janak and A.R. Williams. (1978). Calculated Electronic Properties of Metals. Pergamon Press. Oxford - England. 
